\title{
Aktivitas NORM pada Sedimen Dasar di Perairan PLTU Tanjung Jati Jepara dan Kaitannya dengan Ukuran Butir Sedimen serta TOC
}

\section{NORM Activity on Sediment Basement in the Waters of PLTU Tanjung Jati Jepara Water and Its Relation to Sediment Grain Size and TOC}

\author{
Navila Bidasari Alviandini ${ }^{1}$, Muslim ${ }^{1}$, Wahyu Retno Prihatiningsih ${ }^{2}$, Sri Yulina Wulandari \\ ${ }^{1}$ Departemen Oseanografi, Fakultas Perikanan dan Ilmu Kelautan, Universitas Diponegoro \\ Jl. Prof. H. Soedharto, SH, Tembalang Semarang, Indonesia 50275 \\ ${ }^{2}$ Pusat Teknologi Keselamatan dan Metrologi Radiasi-BATAN \\ Jl. Lebak Bulus Raya No. 49, Kotak Pos 7043 JKSKL Jakarta, Indonesia, 12070 \\ *E-mail: ayu-iu@batan.go.id
}

Naskah diterima: 7 November 2019, direvisi: 20 November 2019, disetujui: 25 November 2019

DOI: $10.17146 /$ eksplorium.2019.40.2.5662

\begin{abstract}
ABSTRAK
NORM (Naturally Occuring Radioactive Material) merupakan unsur radionuklida yang secara alami sudah ada dalam bumi dan kandungannya dapat meningkat dengan adanya kegiatan industri, seperti PLTU. Kegiatan PLTU menghasilkan bottom ash dan fly ash yang akan terbawa oleh angin kemudian masuk ke perairan dan mengendap pada sedimen dasar perairan. Penelitian ini bertujuan untuk mengetahui aktivitas NORM pada sedimen dasar terkait kegiatan PLTU Tanjung Jati, Jepara dan hubungannya dengan ukuran butir serta TOC (Total Organic Carbon). Pengambilan sampel dilakukan dengan metode purposive sampling. Pengukuran konsentrasi aktivitas NORM dilakukan menggunakan spektrometri sinar gama detektor HPGe, di Laboratorium Radioekologi Kelautan PTKMR-BATAN. Konsentrasi aktivitas NORM yang terdeteksi yaitu ${ }^{40} \mathrm{~K}$ berkisar $442,75-818,40$ Bq. $\mathrm{Kg}^{-1},{ }^{232} \mathrm{Th}$ berkisar $99,19-212,34$ Bq. $\mathrm{Kg}^{-1}$ dan ${ }^{226} \mathrm{Ra}$ berkisar $42,42-77,77$ Bq. $\mathrm{Kg}^{-1}$. Aktivitas NORM menunjukkan adanya hubungan dengan tekstur sedimen, tetapi tidak menunjukkan hubungan dengan kandungan Total Organic Carbon (TOC).
\end{abstract}

Kata kunci: aktivitas NORM, sedimen dasar, perairan PLTU, Total Organic Carbon (TOC)

\begin{abstract}
NORM (Naturally Occurring Radioactive Material) is a radionuclide element which naturally exists in the earth and its content can increased with the presence of industrial activities, such as the PLTU. The PLTU activities produce fly ash and bottom ash which will be carried away by the wind and then fall in the waters and settle on the bottom sediments of the waters. This study was aimed to determine the activity of NORM in bottom sediments related activities PLTU Tanjung Jati Jepara and its relationship with grain size and TOC (Total Organic Carbon). Sampling was conducted by purposive sampling method. NORM activity concentration measurements performed using gamma ray spectrometry HPGe detector, in Marine Radioecology Laboratory PTKMR-BATAN. NORM activity concentration detected is ${ }^{40} \mathrm{~K}$ ranged 442.75 to $818.40 \mathrm{~Bq} \cdot \mathrm{Kg}^{-1},{ }^{232} \mathrm{Th}_{\text {ranged }}$ 99.19 to $212.34 \mathrm{~Bq} \cdot \mathrm{Kg}^{-1}$ and ${ }^{226} \mathrm{Ra}$ ranged 42.42 to $77.77 \mathrm{~Bq} \cdot \mathrm{Kg}^{-1}$. NORM activity shows the relationship with sediment texture, but does not show a relationship with the composition of Total Organic Carbon (TOC).
\end{abstract}

Keywords: NORM, Fly Ash, Power Plant, Coal, Tanjung Jati

\section{PENDAHULUAN}

Pembangkit listrik di Indonesia sebagian besar merupakan pembangkit listrik tenaga uap (PLTU) yang menggunakan bahan bakar batu bara. Penggunaan batu bara sebagai bahan bakar PLTU saat ini mencapai $54 \%$ 
dan diperkirakan akan terus mengalami peningkatan sehingga pada tahun 2024 penggunaannya mencapai $63,7 \%$ [1]. Salah satu PLTU berbahan bakar batu bara yang ada di Indonesia adalah PLTU Tanjung Jati Jepara. PLTU Tanjung Jati mampu memenuhi kebutuhan daya listrik sekitar $9 \%$ dari total daya listrik di Pulau Jawa, Bali, dan Madura serta mempunyai 4 unit dengan spesifikasi yang sama yaitu $4 \times 710 \mathrm{MW}$ [2].

Penggunaan batu bara sebagai bahan bakar PLTU menghasilkan lepasan berupa abu terbang (fly ash) dan abu dasar (bottom ash) yang mengandung radionuklida alam dengan konsentrasi aktivitas tertentu [3]. Fly ash mempunyai berat jenis yang lebih besar dari udara sehingga akan jatuh ke lingkungan sekitar PLTU terutama ke perairan laut [4]. Radionuklida alam yang terkandung dalam fly ash memasuki perairan laut dalam bentuk partikulat dan akan terbawa oleh arus menuju perairan yang lebih tenang kemudian mengendap pada sedimen dasar. Oleh sebab itu, perlu dilakukan penelitian NORM di sedimen untuk mengetahui tingkat akumulasinya [5].

Radionuklida alam atau Naturally Occuring Radioactive Material (NORM) merupakan bahan radioaktif yang terdapat di bumi secara alami. NORM yang ditemukan di lingkungan biasanya unsur ${ }^{40} \mathrm{~K}$ serta anak luruh dari Uranium $\left({ }^{238} \mathrm{U}\right)$, Thorium $\left({ }^{232} \mathrm{Th}\right)$ dan Actinium $\left({ }^{235} \mathrm{U}\right)$, namun untuk Actinium tergolong sangat langka sehingga jarang diketemukan keberadaannya [6]. NORM digolongkan sebagai bahan berbahaya yang dapat merusak kelangsungan makhluk hidup secara langsung dan tidak langsung (BAPEDAL, 1999). NORM yang ada di perairan laut akan berpotensi mengalami peningkatan akibat adanya kegiatan industri seperti PLTU.
Kandungan NORM dari operasional PLTU yang masuk perairan tergantung pada suhu pembakaran, efisiensi alat pengendali emisi, ukuran fly ash dan kandungan NORM dalam batu bara [7]. Tinggi rendahnya NORM pada sedimen juga dipengaruhi oleh ukuran butir dan kandungan TOC karena adanya pengaruh ikatan kimia dalam sedimen. Selain itu TOC dapat menjadi indikator dari kuat lemahnya arus dan lokasi pengendapan sedimen [8]. Efek keberadaan NORM dari operasional PLTU dan mobilitasnya dalam lingkungan terutama lingkungan perairan menjadi masalah yang perlu diobservasi lebih lanjut.

Studi terkait keberadaan radionuklida di perairan Indonesia telah banyak dilakukan sebelumnya [9-11], namun penelitian tersebut hanya fokus pada distribusi radionuklida antropogenik ${ }^{137} \mathrm{Cs}$. Studi mengenai distribusi NORM $\left({ }^{232} \mathrm{Th}\right.$ dan $\left.{ }^{226} \mathrm{Ra}\right)$ di Indonesia pernah dilakukan di pesisir Pulau Bangka [12]. Di sisi lain, studi peningkatan aktivitas NORM akibat operasional PLTU pernah dilakukan di Lodz Polandia [13] dan di India [14]. Penelitian sejenis di Indonesia masih sangat terbatas, penelitian NORM terkait operasional PLTU baru dilakukan di PLTU Labuan [7] dan PLTU Rembang [15], sedangkan penelitian NORM pada sedimen di PLTU Tanjung Jati belum pernah dilakukan. Sehingga penelitian ini diperlukan dengan tujuan untuk mengkaji lebih lanjut aktivitas NORM akibat operasional PLTU tanjung Jati Jepara terkait karakteristik ukuran butir sedimen dan kandungan TOC. Hasil penelitian diharapkan dapat digunakan sebagai salah satu acuan data keberadaan NORM untuk merumuskan kebijakan terkait kelestarian dan keselamatan ekosistem. 


\section{METODOLOGI}

\section{Metode Penentuan Lokasi}

Metode yang digunakan dalam penentuan lokasi penelitian ini adalah metode purposive sampling, karena mampu merepresentasikan keadaan lokasi secara keseluruhan berdasarkan pertimbangan dari peneliti [16]. Faktor yang menjadi pertimbangan dari penentuan titik sampel didasarkan pada jarak dengan sumber (PLTU) serta masukan dari sumber lain. Terdapat 6 titik pengambilan sampel, stasiun 1 mewakili perairan yang dekat dengan muara sungai, stasiun 2 mewakili perairan pantai, stasiun 3 mewakili perairan dekat dermaga bongkar muat batubara, stasiun 4 mewakili perairan dekat PLTU, stasiun 5 mewakili jalur pelayaran kapal tongkang dan stasiun 6 mewakili perairan laut lepas (Gambar 1). Penentuan titik lokasi dilakukan menggunakan Global Position System (GPS). Sedangkan pembuatan peta menggunakan perangkat lunak ArcGis 10.3.

\section{Metode Pengambilan Sampel}

Pengambilan sampel sedimen laut dilakukan pada koordinat stasiun yang telah ditentukan dan dimasukkan dalam GPS. Sampel sedimen diambil sebanyak $2-3 \mathrm{Kg}$ dengan menggunakan Sediment Grab kemudian dimasukkan dalam Plastik ziplock dan diberi label.

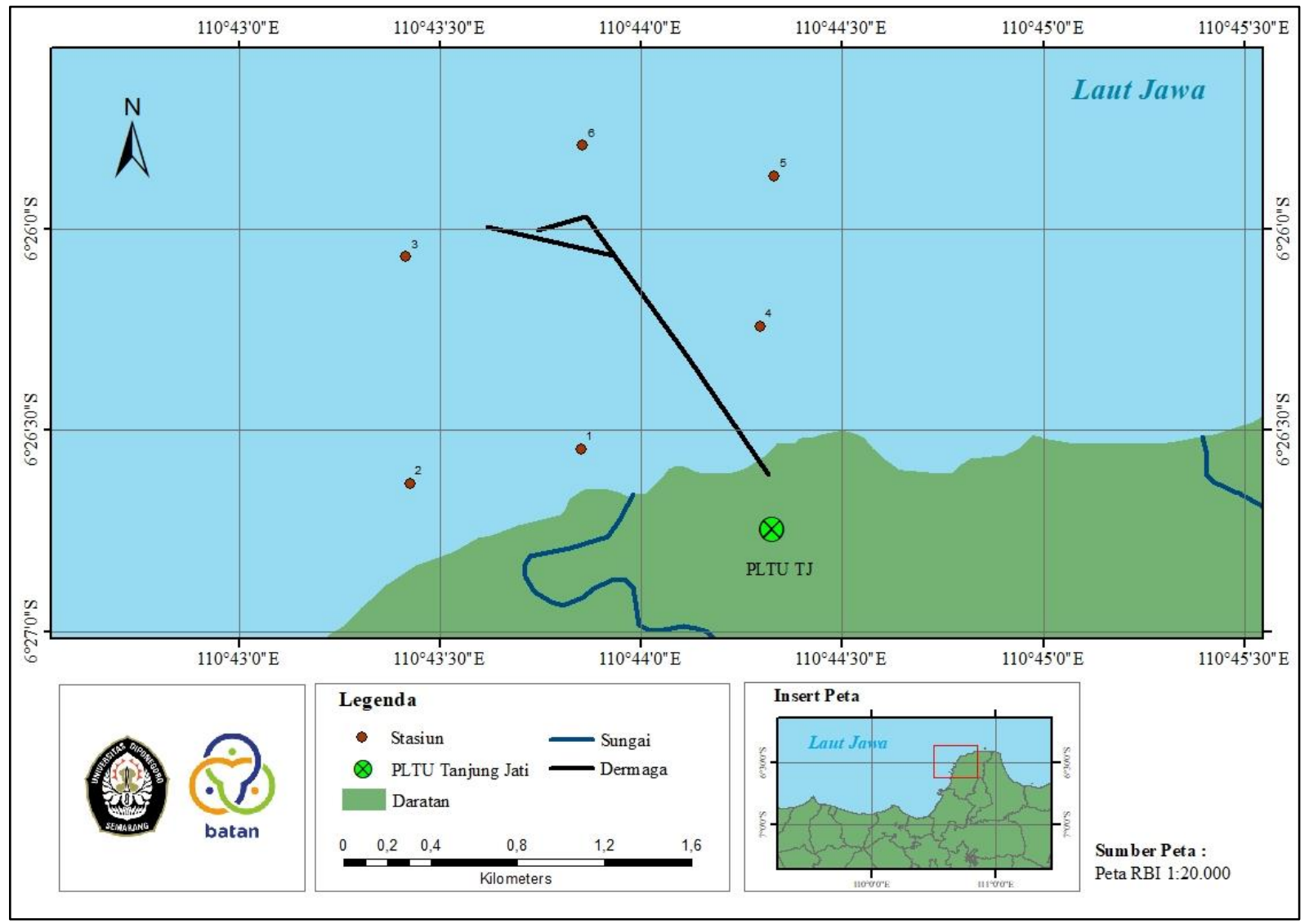

Gambar 1. Peta lokasi penelitian. 


\section{Metode Analisis Data NORM}

Metode yang digunakan dalam menentukan konsentrasi NORM dalam sedimen berpedoman pada metode yang digunakan oleh International Atomic Energy Agency's Marine Environmental Laboratories (IAEA-MEL). Sampel sedimen dikeringkan di bawah sinar matahari selama kurang lebih 3 hari kemudian dikeringkan di dalam oven suhu $80{ }^{\circ} \mathrm{C}$ selama 8 jam. Setelah kering sampel sedimen dihaluskan menggunakan grinder dengan ukuran 50 mikron. Sampel yang sudah halus diambil sebanyak 1000 gram dan dimasukkan ke dalam marinelli untuk didiamkan selama kurang lebih 22 hari untuk mencapai Seqular Equilibrium dan selanjutnya dilakukan pengukuran (counting) menggunakan Gamma Spectrometer HPGe selama 3 hari. Aktivitas ${ }^{232} \mathrm{Th}$ dapat diukur dari aktivitas anak luruhnya, yaitu aktivitas rata-rata ${ }^{212} \mathrm{~Pb}$ dan ${ }^{228}$ Ac. Adapun aktivitas ${ }^{226} \mathrm{Ra}$ diukur dari rata-rata aktivitas ${ }^{214} \mathrm{~Pb}$ dan ${ }^{214} \mathrm{Bi}$.

\section{Metode Analisis Butir Sedimen}

Sampel sedimen dianalisis ukuran butirnya dengan menggunakan metode granulometri. Metode yang digunakan dalam penelitian ini yaitu pemipetan. Sedimen yang digunakan sebanyak 100 gr, kemudian dilarutkan ke dalam gelas ukur $1 \mathrm{~L}$ yang berisi aquadest $1 \mathrm{~L}$, sampel sedimen diaduk hingga homogen kemudian dilakukan pemipetan menggunakan pipet volume sesuai dengan jarak tenggelam dan rentang waktu tertentu. Hasil dari pemipetan per waktu disaring dengan kertas whattman yang kemudian dikeringkan di oven dan ditimbang untuk dianalisis ukuran butirnya.

\section{Metode Analisis Karbon}

Analisis kandungan Total Organic Carbon (TOC) adalah dengan menggunakan metode Loss-On Ignition (LOI). Metode ini dapat menentukan kandungan karbon organik dalam sedimen dengan menggunakan hubungan linear antara nilai LOI dan kandungan karbon organik inorganik [17].

Pada metode ini digunakan sampel sedimen kering sebanyak 5 gram, kemudian ditambahkan $\mathrm{HCl} 6 \mathrm{M}$ sebanyak $10 \mathrm{ml}$, sedimen kemudian dibilas sampai berwarna bening menggunakan aquades untuk menghilangkan garamnya. Sampel sedimen kemudian dioven dengan suhu $60{ }^{\circ} \mathrm{C}$ sampai mencapai kondisi sedimen kering dan dimasukkan ke dalam desikator untuk menurunkan suhunya. Selanjutnya sampel ditimbang sebagai berat awal sampel sedimen $\left(\mathrm{DW}_{150}\right)$, kemudian dimasukkan ke dalam muffle furnace dengan suhu $550{ }^{\circ} \mathrm{C}$ selama 6 jam. Setelah proses pengabuan selesai sampel dimasukkan ke dalam desikator sebelum ditimbang kembali sebagai berat akhir $\left(\mathrm{DW}_{550}\right)$ [18]. Selanjutnya, sampel dihitung dengan menggunakan perhitungan presentase kandungan karbon organik total dalam sedimen menggunakan persamaan sebagai berikut:

$$
\% \text { TOC }=\left(\frac{\left(D W_{150}-D W_{550}\right)}{D W_{150}}\right) \times 100 \%
$$

Nilai \%TOC adalah presentase kandungan karbon organik total dalam sedimen (\%), $\mathrm{DW}_{150}$ adalah berat sedimen sebelum pengabuan (gram) dan $\mathrm{DW}_{550}$ adalah berat sedimen setelah pengabuan (gram).

\section{Metode Analisis Korelasi}

Analisis statistik yang digunakan dalam penelitian ini adalah analisis Korelasi Pearson yang hasilnya digunakan untuk mengetahui 
kuat lemahnya hubungan antar variabel. Nilai korelasi berada pada rentang nilai 1 dan -1 . Suatu hubungan dikatakan kuat ketika nilai korelasinya lebih besar dari 0,5 atau lebih kecil dari -0,5 [19]. Adapun, ketika korelasinya bernilai positif berarti hubungannya bersifat searah dan apabila korelasinya menunjukkan angka negatif berarti hubungan bersifat tidak searah.

Analisis komponen utama (PCA) merupakan sebuah metode statistik yang dapat digunakan untuk mengetahui pengaruh variabel yang paling berkaitan antara banyak variabel. Hasil analisis dari PCA adalah grafik biplot yang menggambarkan korelasi antarvariabel dalam ruang dari dua komponen utama [20]. Pada tahap analisis komponen utama menggunakan perangkat lunak XLStat 2018, yang hasilnya berupa hubungan antara variabel dengan stasiun pengambilan data.

\section{HASIL DAN PEMBAHASAN Aktivitas NORM}

Ditinjau dari Gambar 2, Aktivitas NORM tertinggi yaitu unsur ${ }^{40} \mathrm{~K}$ di stasiun 6 , dengan aktivitas $818,40 \mathrm{~Bq} \cdot \mathrm{Kg}^{-1}$ dan terendah pada unsur ${ }^{226} \mathrm{Ra}$ di stasiun 2 dengan aktivitas 42,42 Bq. $\mathrm{Kg}^{-1}$. Unsur ${ }^{40} \mathrm{~K}$ mempunyai kisaran nilai aktivitas $442,75-818,40 \mathrm{~Bq} \cdot \mathrm{Kg}^{-1}$ dan rata-rata aktivitas sebesar $678,86 \mathrm{~Bq} \cdot \mathrm{Kg}^{-1}$. Unsur ${ }^{232}$ Th berkisar 99,19-212,34 Bq. $\mathrm{Kg}^{-1}$ dengan aktivitas rata-rata sebesar 136,21 Bq. $\mathrm{Kg}^{-1}$ dan untuk unsur ${ }^{226} \mathrm{Ra}$ berkisar antara 42,42-77,77 Bq. $\mathrm{Kg}^{-1}$ dengan aktivitas ratarata sebesar $65.43 \mathrm{~Bq} . \mathrm{Kg}^{-1}$.

Aktivitas tertinggi ke terendah secara berturut-turut adalah unsur ${ }^{40} \mathrm{~K},{ }^{232} \mathrm{Th}$ dan ${ }^{226}$ Ra. Aktivitas NORM pada lingkungan perairan dipengaruhi oleh sifat dari tiap unsur radionuklida itu sendiri. Sesuai dengan penelitian yang pernah dilakukan terdahulu [21], bahwa unsur ${ }^{226} \mathrm{Ra}$ mempunyai aktivitas yang cenderung rendah pada sedimen karena sifat kelarutannya yang tinggi, aktivitas ${ }^{232} \mathrm{Th}$ juga termasuk rendah karena pengaruh mobilitas geokimianya yang rendah. Adapun radionuklida ${ }^{40} \mathrm{~K}$ mempunyai aktivitas yang tertinggi dibandingkan unsur lainnya, tingginya aktivitas ${ }^{40} \mathrm{~K}$ di alam karena berasal dari radiasi kosmik di atmosfir yang telah terjadi sejak awal pembentukan bumi, sehingga kandungannya selalu bertambah [22]. Hal ini juga diperkuat oleh penelitian terdahulu [23], yang menyatakan bahwa melimpahnya unsur ${ }^{40} \mathrm{~K}$ di alam disebabkan oleh kandungannya yang melimpah pada batuan serta mineral ringan. Nilai aktivitas ${ }^{40} \mathrm{~K}$ di PLTU Tanjung Jati, Jepara berkisar 442,75-818,40 Bq. $\mathrm{Kg}^{-1}$ (Gambar 2) lebih tinggi dibandingkan penelitian terdahulu [24] di Pulau Tikus dengan nilai aktivitas ${ }^{40} \mathrm{~K}$ 61,62-152,24 Bq. $\mathrm{Kg}^{-1}$. Tingginya aktivitas ini, menunjukkan terjadinya pengkayaan radionuklida pada sedimen yang berasal dari kegiatan PLTU. Meskipun demikian, aktivitas NORM di sedimen perairan PLTU Tanjung Jati Jepara masih tergolong aman apabila ditinjau dari peraturan BAPETEN [25], yang menyatakan nilai ambang batas untuk turunan ${ }^{226} \mathrm{Ra}$ adalah $300 \mathrm{~Bq} \cdot \mathrm{Kg}^{-1}$, untuk turunan ${ }^{232} \mathrm{Th}$ sebesar $10.000 \mathrm{~Bq} \cdot \mathrm{Kg}^{-1}$ dan unsur ${ }^{40} \mathrm{~K}$ adalah $3.000 \mathrm{~Bq} \cdot \mathrm{Kg}^{-1}$.

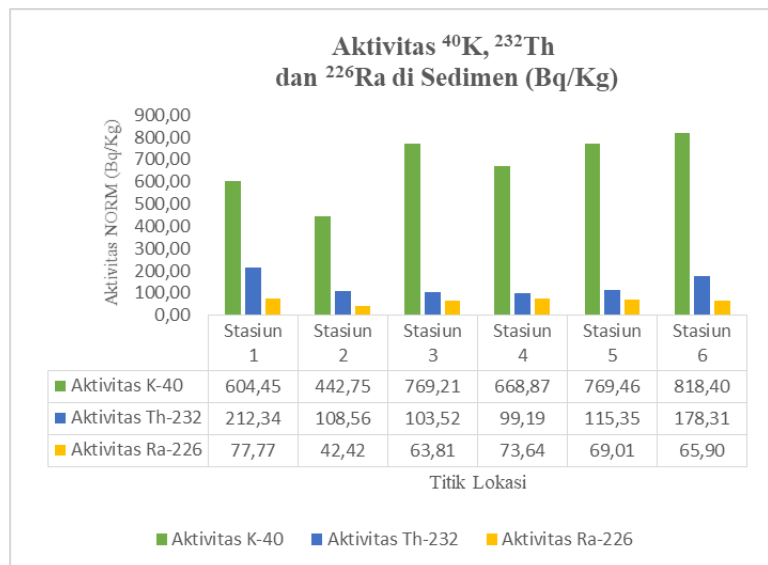

Gambar 2. Grafik aktivitas NORM pada sedimen di perairan PLTU Tanjung Jati Jepara. 
Aktivitas ${ }^{226} \mathrm{Ra}$ dan ${ }^{232}$ Th tertinggi pada stasiun 1 sedangkan ${ }^{40} \mathrm{~K}$ tertinggi pada stasiun 6. Tingginya aktivitas ${ }^{226} \mathrm{Ra}$ dan ${ }^{232} \mathrm{Th}$ pada stasiun 1 diduga dipengaruhi oleh lokasi yang dekat dengan muara sungai, sehingga mendapatkan pengaruh luar seperti limbah rumah tangga ataupun limbah PLTU yang mengalir melalui sungai tersebut. Hal ini sesuai dengan penelitian terdahulu [26] yang menyatakan bahwa kandungan radionuklida mengalami peningkatan sepanjang hulu sampai hilir sungai yang dipengaruhi oleh adanya masukan yang terjadi sepanjang sungai. Tingginya aktivitas ${ }^{226} \mathrm{Ra}$ dan ${ }^{232} \mathrm{Th}$ pada stasiun 1 juga dipengaruhi oleh ukuran butir yang didominasi jenis lanau (Tabel 1), sehingga mempunyai daya adsorbsi yang besar. Hal ini sesuai dengan penelitian terdahulu [27], bahwa ukuran butir yang halus mempunyai luas permukaan yang lebih besar sehingga mampu mengikat unsur lebih banyak dan kuat daripada ukuran butir yang kasar. Adapun aktivitas ${ }^{40} \mathrm{~K}$ tertinggi pada stasiun 6 hal ini berhubungan dengan kestabilan unsur ${ }^{40} \mathrm{~K}$, dimana unsur ${ }^{40} \mathrm{~K}$ pada sedimen yang berada di perairan laut lepas lebih stabil dibandingkan dekat pantai.

Pada stasiun 2 rata-rata aktivitas unsur NORM rendah. Hal ini diduga adanya pengaruh ukuran butir pasir yang bertekstur kasar pada lokasi ini (Tabel 1). Hal ini sesuai dengan pernyataan pada penelitian terdahulu [28], bahwa sedimen dengan ukuran butir yang kasar mempunyai kekuatan ikat dan kemampuan menangkap zat kimia yang rendah.

Kandungan (Total Carbon) TC terbesar terdapat pada stasiun 1 dengan nilai $15,32 \%$ dan nilai TC terendah pada stasiun 4 dengan nilai $9,90 \%$. Nilai TOC tertinggi pada stasiun 3 dengan nilai $13,60 \%$ dan nilai TOC terendah pada stasiun 6 dengan nilai $3,36 \%$.
Untuk nilai (Total Inorganic Carbon) TIC yang terbesar pada stasiun 6 dengan nilai $10,88 \%$ dan nilai terendah pada stasiun 3 dengan nilai $1,11 \%$ (Tabel 2).

Tabel 1. Klasifikasi ukuran butir sedimen.

\begin{tabular}{ccccc}
\hline \multirow{2}{*}{ Stasiun } & \multicolumn{3}{c}{ Ukuran Butir (\%) } & Jenis \\
\cline { 2 - 4 } & Pasir & Lanau & Lempung & Sedimen \\
\hline 1 & 9,91 & 89,74 & 0,35 & Lanau \\
2 & 99,43 & 0,541 & 0,028 & Pasir \\
3 & 4,35 & 95,408 & 0,242 & Lanau \\
& & & 0,683 & Pasir \\
4 & 68,23 & 31,086 & berlanau \\
5 & 5,69 & 94,183 & 0,126 & Lanau \\
6 & 3,88 & 90,813 & 5,03 & Lanau \\
\hline
\end{tabular}

Tabel 2. Kandungan karbon sedimen.

\begin{tabular}{cccc}
\hline \multirow{2}{*}{ Stasiun } & \multicolumn{3}{c}{ Kandungan Karbon $(\%)$} \\
\cline { 2 - 4 } & TC & TOC & TIC \\
\hline 1 & 15,32 & 12,76 & 2,56 \\
2 & 10,51 & 7,82 & 2,68 \\
3 & 14,71 & 13,60 & 1,11 \\
4 & 9,90 & 8,23 & 1,67 \\
5 & 14,17 & 12,13 & 2,04 \\
6 & 14,24 & 3,36 & 10,88 \\
\hline
\end{tabular}

\section{Hubungan NORM dengan Kandungan Karbon dan Ukuran Butir}

Berdasarkan hasil korelasi Pearson, terdapat nilai yang positif untuk hubungan lanau dengan hampir semua variabel dan merupakan hubungan yang paling kuat (Tabel 3). Adapun untuk hubungan sedimen bertekstur kasar seperti pasir dengan semua parameter bernilai negatif, sehingga menggambarkan suatu hubungan yang berkebalikan. Sedimen halus mempunyai luas permukaan yang lebih besar sehingga radionuklida akan terperangkap lebih banyak dalam sedimen halus daripada sedimen dengan tekstur yang kasar [28]. Tekstur sedimen yang halus berperan dalam hal pelekatan dan deposisi kontaminan kimia melalui proses adsorpsi permukaan. 
Pada penelitian ini, hubungan tekstur sedimen lanau lebih berpengaruh terhadap NORM dibandingkan dengan TOC. Hal ini diduga dipengaruhi oleh interaksi antara karbon dengan sedimen bertekstur halus dan radionuklida, sebagaimana dalam penelitian terdahulu [29] yang menyatakan bahwa kandungan karbon yang tinggi akan cenderung megambil alih ruang penyerapan dalam sedimen, sehingga sedimen lebih cenderung berikatan dengan karbon daripada radionuklida. Dalam penelitian lain [30] menyatakan bahwa radionuklida akan berikatan kuat dengan organik karbon dan kurang kuat berikatan dengan sedimen tekstur halus karena berkurangnya kapasitas pertukaran kation dalam sedimen.

Berdasarkan plot yang dihasilkan dari analisis biplot dapat menjelaskan 81,69\% dari keseluruhan data (Gambar 3). Hasil ini menunjukkan bahwa sedimen jenis pasir mempunyai hubungan pada stasiun 2 dan 4 . Hal ini selaras dengan rendahnya aktivitas NORM di stasiun 2 dan 4.

\section{Hubungan NORM dengan angin dan arus pasang surut}

Berdasarkan hasil pemodelan arus di perairan PLTU Tanjung Jati Jepara menggunakan MIKE 21 menghasilkan arah dan kecepatan arus. Kecepatan arus pada saat pasang sebesar $0,11 \mathrm{~m} / \mathrm{s}$ dengan arahnya dari timur menuju barat daya (Gambar 4) dan kecepatan arus pada saat surut sebesar 0,17 $\mathrm{m} / \mathrm{s}$ dengan arah cenderung dari utara menuju timur (Gambar 5). Nilai kecepatan arus termasuk kecil sehingga kurang kuat dalam mempengaruhi transpor sedimen di laut. Kecepatan arus yang kurang dari 0,5 m/s tidak akan berpengaruh pada transpor sedimen karena kurang mampu dalam menggerakkan sedimen [31]. Kurangnya pengaruh arus terhadap transport sedimen juga arus NORM yang terikat di sedimen lokasi ini relatif kecil yaitu kurang dari 0,5 $\mathrm{m} / \mathrm{s}[31]$.

Pengaruh faktor angin (Gambar 6, 7, 8 dan 9) dapat dilihat pada stasiun 4 yang lokasinya paling dekat dengan PLTU tetapi mempunyai konsentrasi aktivitas NORM yang relatif kecil dibandingkan penelitian NORM terdahulu [23]. Hal ini diduga disebabkan pengaruh angin yang selama 5 tahun arah dominannya dari timur menuju barat laut, sehingga fly ash yang keluar dari cerobong PLTU akan cenderung terdistribusi pada titik lokasi sebelah barat laut dari cerobong, seperti stasiun 1 .

Tabel 3. Hubungan karakteristik sedimen dan kandungan karbon dengan NORM.

\begin{tabular}{|c|c|c|c|c|c|c|c|c|c|}
\hline Variabel & ${ }^{40} \mathrm{~K}$ & ${ }^{232} \mathrm{Th}$ & ${ }^{226} \mathrm{Ra}$ & Pasir & Lanau & Lempung & $\mathrm{TC}$ & TOC & TIC \\
\hline${ }^{40} \mathrm{~K}$ & & 0,069 & 0,542 & $-0,811$ & 0,798 & 0,512 & 0,544 & $-0,030$ & 0,377 \\
\hline${ }^{232} \mathrm{Th}$ & & & 0,434 & $-0,471$ & 0,456 & 0,437 & 0,604 & $-0,114$ & 0,504 \\
\hline${ }^{226} \mathrm{Ra}$ & & & & $-0,620$ & 0,625 & 0,097 & 0,436 & 0,283 & $-0,025$ \\
\hline Pasir & & & & & $-0,999$ & $-0,327$ & $-0,924$ & $-0,297$ & $-0,268$ \\
\hline Lanau & & & & & & 0,281 & 0,928 & 0,342 & 0,223 \\
\hline Lempung & & & & & & & 0,199 & $-0,796$ & 0,974 \\
\hline $\mathrm{TC}$ & & & & & & & & 0,398 & 0,208 \\
\hline TOC & & & & & & & & & $-0,814$ \\
\hline TIC & & & & & & & & & \\
\hline
\end{tabular}




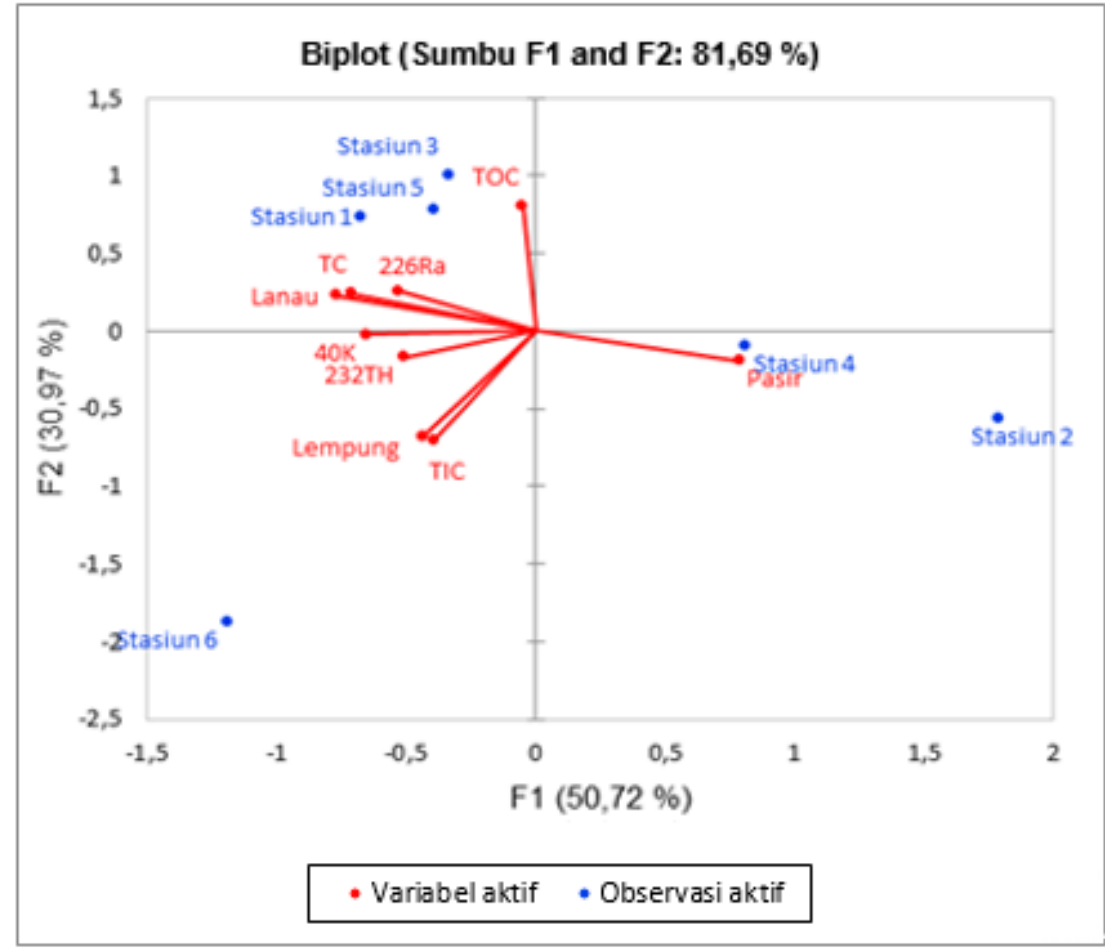

Gambar 3. Biplot NORM dengan karakteristik sedimen dan kandungan karbon.

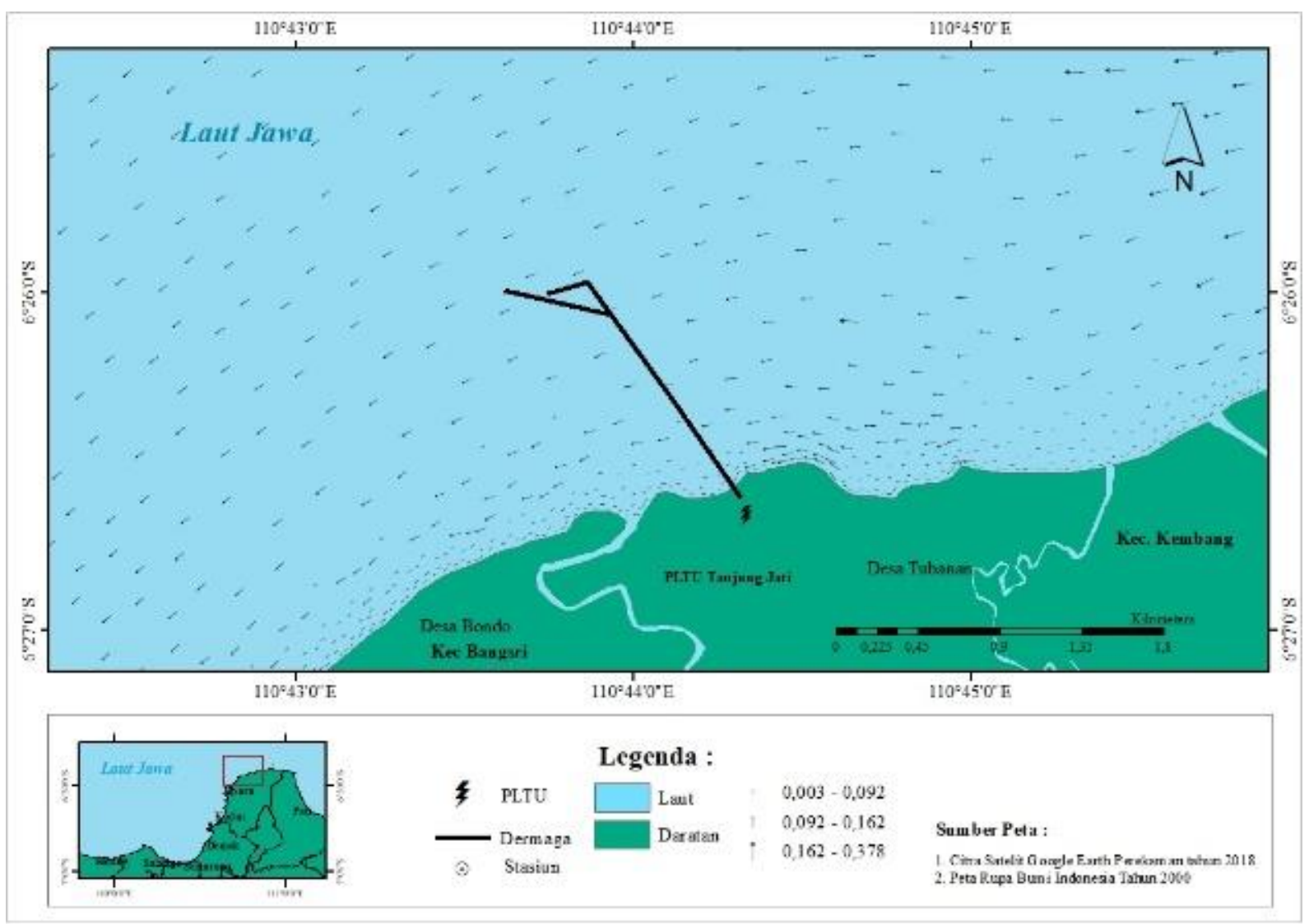

Gambar 4. Pola arus pada saat pasang. 


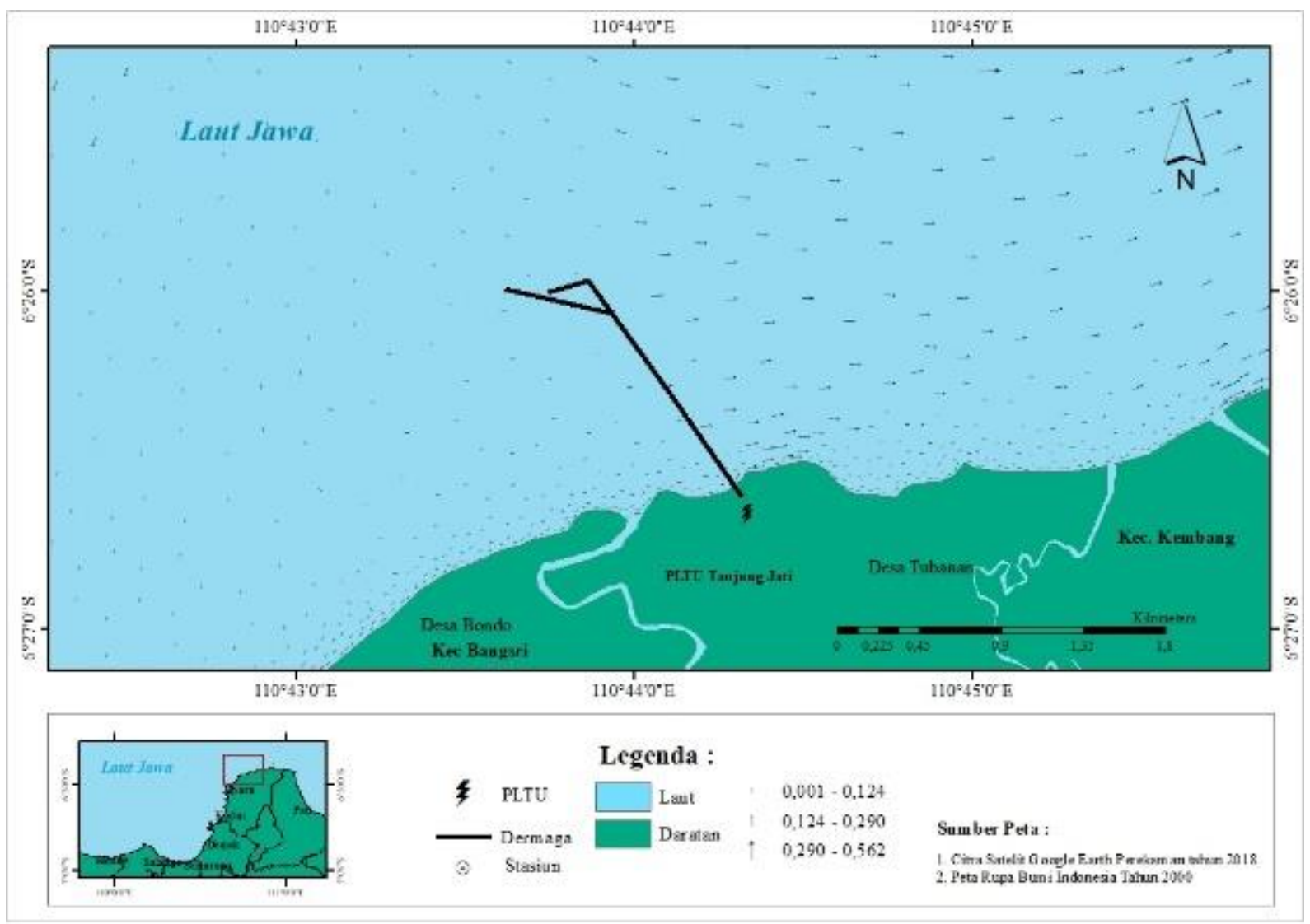

Gambar 5. Pola arus pada saat pasang surut.
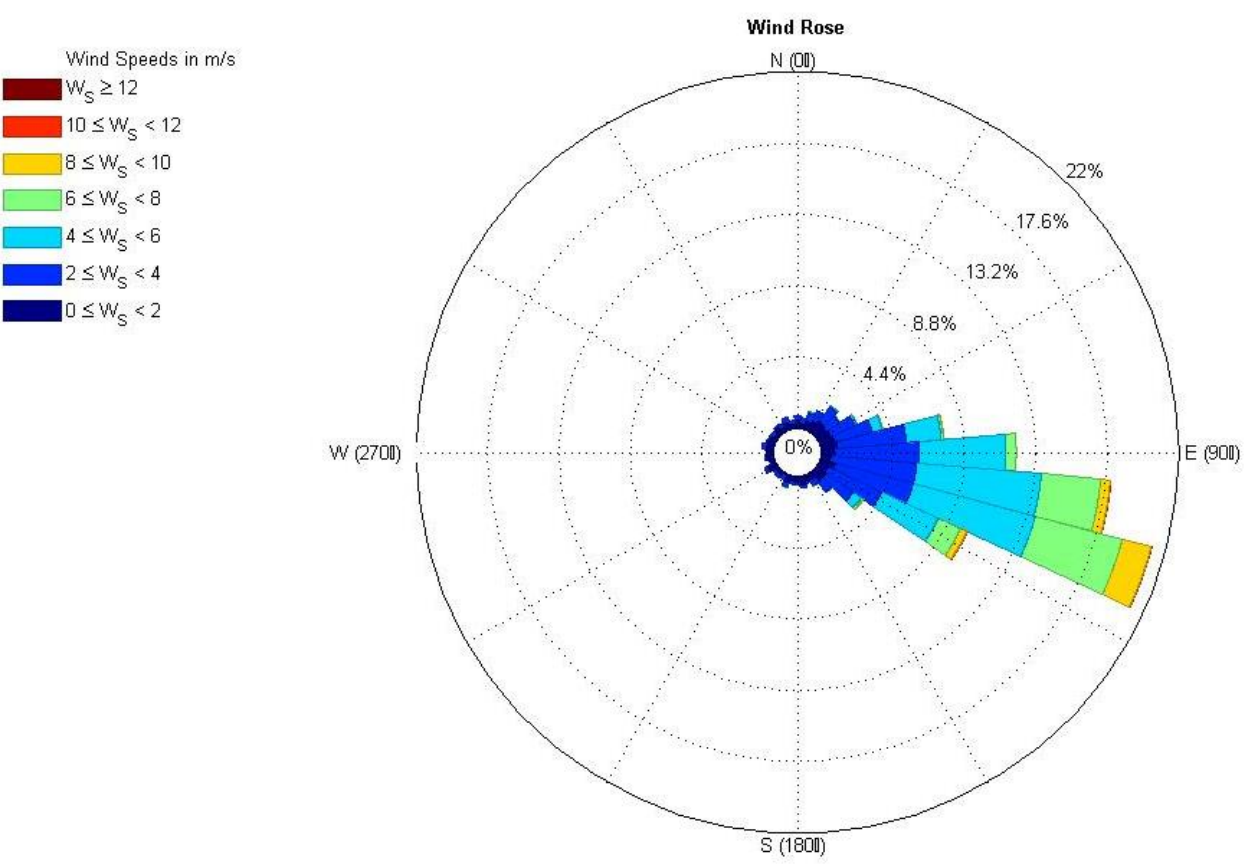

Gambar 6. Windrose musim barat (2013-2018). 

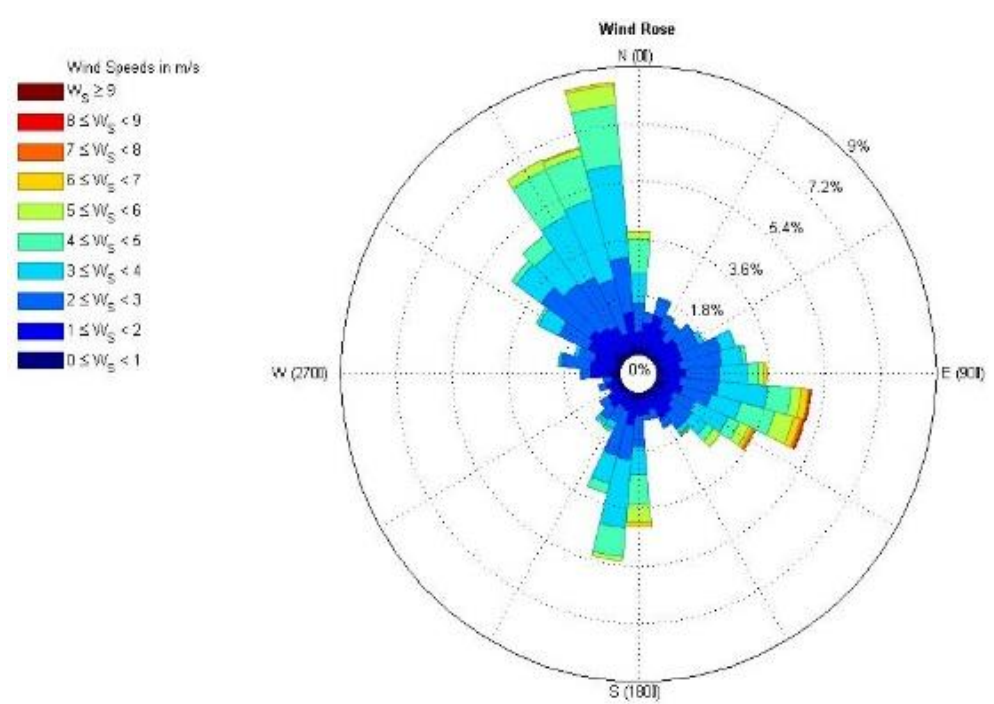

Gambar 7. Windrose musim peralihan 1(2013-2018).

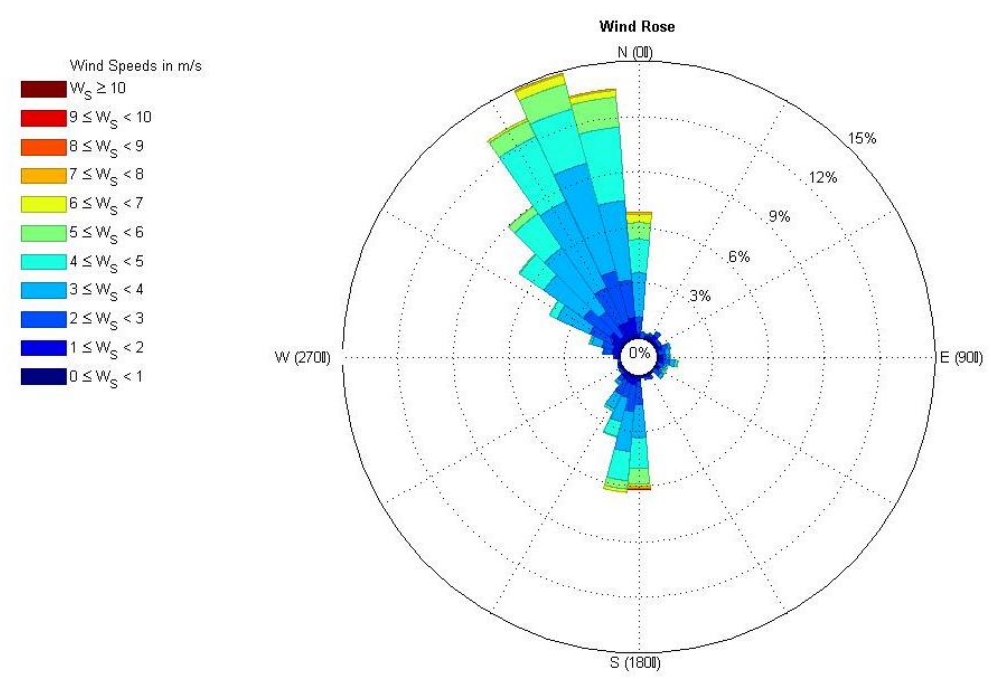

Gambar 8. Windrose musim timur (2013-2018).

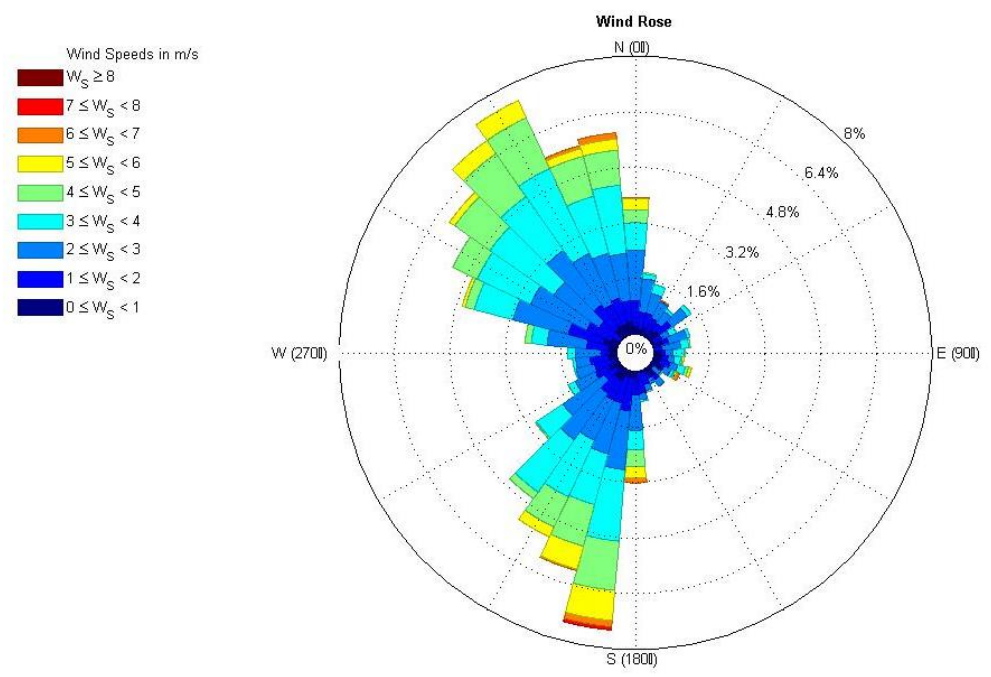

Gambar 9. Windrose musim peralihan 2 (2013-2018). 


\section{KESIMPULAN}

Berdasarkan hasil penelitian yang telah dilaksanakan dapat disimpulkan bahwa radionuklida alam (NORM) yang terdeteksi pada penelitian ini adalah unsur ${ }^{40} \mathrm{~K}$, unsur ${ }^{232} \mathrm{Th}$ dan unsur ${ }^{226} \mathrm{Ra}$ dengan aktivitasnya secara berturut-turut berada pada kisaran 442,75-818,40 Bq. $\mathrm{Kg}^{-1}, \quad$ 99,19-212,34 Bq. $\mathrm{Kg}^{-1}$ dan $42,42-77,77$ Bq. $\mathrm{Kg}^{-1}$. Aktivitas NORM pada perairan PLTU Tanjung Jati, Jepara masih tergolong aman karena aktivitasnya berada di bawah baku mutu BAPETEN. Aktivitas NORM di Perairan PLTU Tanjung Jati Jepara, menunjukkan adanya hubungan yang tinggi dengan tekstur sedimen lanau, tetapi aktivitas ini kurang berhubungan dengan TOC dan arus.

\section{UCAPAN TERIMA KASIH}

Penulis sampaikan terimakasih kepada Pusat Teknologi Keselamatan dan Metrologi Radiasi, Badan Tenaga Nuklir Nasional atas dukungan dana penelitian dan laboratorium untuk kegiatan penelitian. Penulis Juga mengucapkan terima kasih atas dukungan kegiatan penelitian dari Fakultas Perikanan dan Ilmu Kelautan,Universitas Diponegoro. WRP dan M dalam makalah ini merupakan kontributor utama dalam penelitian dan penulisan makalah ini.

\section{DAFTAR PUSTAKA}

[1] Cahyadi, PLTU Batu Bara Super kritikal yang Efisien $\left(I^{\text {st }}\right.$ ed.). Tangerang Selatan, Banten, Balai Besar Teknologi Energi (B2TE), BPPT, 2015.

[2] T. Juliandhy, T. Haryono dan Suharyanto., "Efek Kegagalan Alat Flue Gas Desulphur Terhadap Tegangan Lewat Denyar Isolator," JNTETI. 3(2):142-145, 2014.

[3] B. Ozden, E. Guler, T. Vaasma, M. Horvath and M. Kiisk, "Enrichment of Naturally Occurring Radionuclides and Trace Elements in Yatagan and Yenikoy Coal-Fired Thermal Power Plants, Turkey", Journal of Environmental, 188: 100107, 2017.

[4] Y. M. Amin, M. U. Khandaker, A. K. S. Shyen, R. H. Mahat, R. M. Nor and D. A. Bradley,
"Radionuclide Emissions From a Coal-Fired Power Plant," Applied Radiation and Isotopes. 80:109-116, 2013.

[5] J. Vives, M. Aoyama, C. Bradshaw, J. Brown, K. O. Buesseler, N. Casacuberta and J. Nishikawa, "Science of the Total Environment Marine Radioecology After the Fukushima Dai-Ichi Nuclear Accident: Are We Better Positioned To Understand The Impact Of Radionuclides In Marine Ecosystems?" Science of the Total Environment, 618:80-92, 2018.

[6] M. I. Ojovan, and W. E. Lee, "Nuclear Decay", In An Introduction to Nuclear Waste Immobilisation, p: 7-19, 2014.

[7] N. H. Anggraini, D. Iskandar dan M. Stefanus, "Studi Peningkatan Radionuklida Alam Karena Lepasan Abu Terbang di Sekitar PLTU Labuan," Sains dan Teknologi Nuklir Indonesia 19(1): 2940, 2018.

[8] F. M. G. Carvalho, D. da C. Lauria, F. Ribeiro, R. T. Fonseca, S. da S. Peres and N. S. F. Martins, "Natural and Man-Made Radionuclides in Sediments of An Inlet in Rio de Janeiro State, Brazil". Marine Pollution Bulletin. 107(1):269276, 2016.

[9] H. Suseno, and W. R. Prihatiningsih, "Monitoring 137Cs and134Cs at marine coasts in Indonesia between 2011 and 2013," Marine Pollution Bulletin, 88(1-2), 319-324, 2014. http://doi.org/10.1016/j.marpolbul.2014.08.024.

[10] H. Suseno, I. B. Wahono, and M. Muslim, "Radiocesium monitoring in Indonesian waters of the Indian Ocean after the Fukushima nuclear accident," Marine Pollution Bulletin, 97(1-2), 539-543, 2015.

http://doi.org/10.1016/j.marpolbul.2015.05.015.

[11] H. Suseno, I. B. Wahono, M. Muslim, and M. N. Yahya, "Status of $137 \mathrm{Cs}$ concentrations in sea water at the inlets of the Indonesian Through Flow (ITF)," Regional Studies in Marine Science, 10, 81-85, 2017. http://doi.org/10.1016/j.rsma.2016.12.008.

[12] W. R. Prihatiningsih, dan H. Suseno, "Status Konsentrasi 232 Th dan 226 Ra dalam Sedimen Pesisir Pulau Bangka", Jurnal Teknologi Pengelolaaan Limbah. 15(2):65-70, 2012.

[13] H. Bem, P. Wieczorkowski and M. Budzanowski, "Evaluation of Technologically Enhanced Natural Radiation Near the Coal-Fired Power Plants in the Lodz Region of Poland," Journal Of Environmental Radioactivity. 61:191-201, 2002.

[14] S. K. Sahu, M. Tiwari, R. C. Bhangare and G. G. Pandit, "Enrichment and Particle Size Dependence of Polonium and Other Naturally Occurring Radionuclides in Coal Ash," Journal of Environmental Radioactivity. 138:421-426, 2014.

[15] Y. A. S. Putra, D. P. Sasongko, Z. Arifin dan Sukirno, "Distribusi Radionuklida Alam dalam 
Sampel Lingkungan Tanah, Air dan Tanaman Sekitar PLTU Rembang," Youngster Physics Journal, 6(4):2-9, 2017.

[16] Priyono, Metode Penelitian Kuantitatif. ( $1^{\text {st }}$ ed.). Sidoarjo: Zifatama Publishing, 2016.

[17] J. Liu, H. Wei, K. Zhang and G. Pang, "Robust Stabilisation for Constrained Discrete-Time Switched Positive Linear Systems with Uncertainties," IET Control Theory \& Applications, 9(17):2598-2605, 2015.

[18] J. Meng, P. Yao, Z. Yu, T. S. Bianchi, B. Zhao, H. Pan and D. Li, "Speciation, Bioavailability and Preservation of Phosphorus in Surface Sediments of the Changjiang Estuary and Adjacent East China Sea Inner Shelf," Estuarine, Coastal and Shelf Science. 144:27-38, 2014.

[19] T. Budiwati, A. Budiyono, W. Setyawati dan A. Indrawati, "Analisis Korelasi Pearson Untuk Unsur-Unsur Kimia Air Hujan di Bandung," Jurnal Sains Dirgantara, 7 (2) :110-112, 2010.

[20] A. Al-Sayed, "Principal Component Analysis within Nuclear Structure". Nuclear Physics A 933:154-64, 2015.

[21] C.S. Kaliprasad, and Y. Narayana, "Mineralogy and Physico-Chemical Parameters on the Behavior of Natural Radionuclides in the Riverine Environs of Hemavathi, South India," Radiation Physics and Chemistry. 151: 99-107, 2018.

[22] J. Peterson, M. Macdonell, L. Haroun and F. Monette, "Radiological and Chemical Fact Sheets to Support Risk Analysis Contaminated Areas," Argonne National Labolatory Environmental Science Division . U.S. departement of Energy, 2007.

[23] R. Ravinsankar, J. Chandramohan, A. Chandrasekaran, J. P. P. Jebakumar, I. Vijayalakshmi, P. Vijayagopal and Venkatraman, "Assessments of Radioactivity Concentration of Natural Radionuclides and Radiological Hazard Indices in Sediment Sampels From the East Coast of Tamilnadu, India With Statistical Approach,"
Marine Pollution Bulletin, 97 (1-2): 419-430, 2015.

[24] A. H. Syaher, Muslim dan M. Makmur, "Analisis Kandungan Radionuklida 40K pada Sedimen di Perairan Pulau Tikus, Bengkulu," Journal of Oceanography 4(2): 579-584, 2015.

[25] BAPETEN, "Peraturan mengenai Keselamatan Radiasi Dalam Penyimpanan Technologically Enhanced Naturally Occurring Radioactive Material". Jakarta: Badan Pengawas Tenaga Nuklir, 2013.

[26] B. Zaman, A. Taftazani, R. Pasca, dan S. Retnaningrum, "Studi analisis dan pola persebaran radioaktivitas perairan dan sedimen (studi kasus: sungai code yogyakarta )," Teknik Keairan, 13(4), 215-225, 2007.

[27] M. W. Yii, A. Zaharudin, and M. Norfaizal, "Concentration of radiocaesium $137 \mathrm{Cs}$ and $134 \mathrm{Cs}$ in sediments of the Malaysian marine environment,". Applied Radiation and Isotopes, 65(12), 1389-1395, 2007. http://doi.org/10.1016/j.apradiso.2007.07.002.

[28] M. Dowdall, and A. Lepland, "Elevated Levels of Radium-226 and Radium-228 in Marine Sediments of the Norwegian Trench (" Norskrenna") and Skagerrak," Marine Pollution Bulletin, 64(10):2069-2076, 2012.

[29] H. I. El-reefy, T. Sharshar, R. Zaghloul, dan H. M. Badran, "Distribution of Gamma-Ray Emitting Radionuclides in the Environment of Burullus Lake: I. Soils and Vegetations," $J$ Environ Radioact, 87(2): 148-69, 2006.

[30] C. S. Kaliprasad, and Y. Narayana, "Mineralogy and Physico-Chemical Parameters on the Behavior of Natural Radionuclides in the Riverine Environs of Hemavathi, South India," Radiation Physics and Chemistry. 151: 99-107, 2018.

[31] S. Trianne, A. Satriadi dan L. Maslukah, "Analisis Sebaran Sedimen Dasar di Perairan Tolitoli Sulawesi Tengah," Jurnal Oseanografi, 6: 633-638, 2017. 